\title{
OBITUARY
}

\section{Willie Mukheiber}

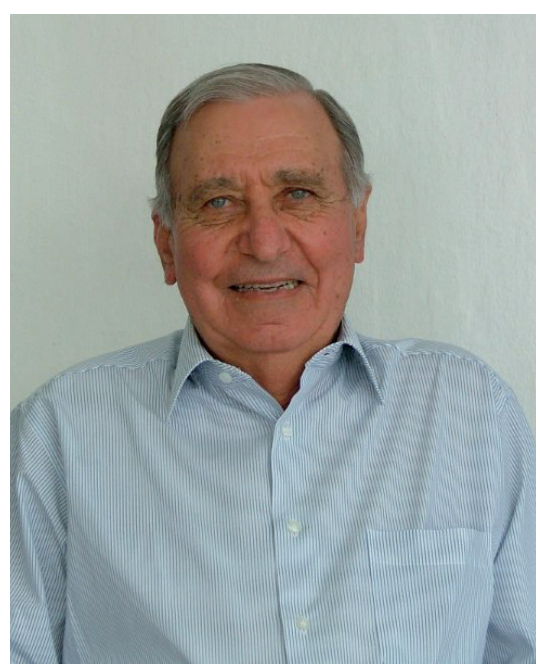

It is with great sadness that I report the death on 11 April 2013 of Willie Mukheiber, one of Nature's thorough gentlemen. Born in Ficksburg on 1 August 1925, he was the second of 3 siblings, and attended the local high school. After matriculating in 1942, he enrolled in the medical faculty at UCT. He was keen to enlist in the SADF but, as he was under age, his mother refused to give him permission to do so. He completed his medical studies in 1949 and served his internship at King Edward VIII Hospital.
While there, he met and married Joan (née Todd), a radiographer, who unfortunately predeceased him by 15 years as a result of cancer. He never recovered fully from her death and for a while was a lonely person.

After completing his internship, he went straight into private practice on the Bluff and built up a thriving practice. He left this, at the urging of Chris Saunders, CEO of Tongaat, who was a great friend of his at varsity, and took up an appointment at the local hospital there. However, this work was not really to his liking, with the routine paperwork and his inability to communicate with his patients, most of whom were Pondo canecutters. He longed for the intimacy of private practice and the warm relationships he developed with his patients.

Willie was kind and generous to a fault. His patients loved him and he was held in the highest esteem by his colleagues. After joining Barry Stacey and Mike Blanckenberg, his practice continued to grow. He became a staunch friend as well as a loyal supporter of mine. Illness forced him to retire early initially severe vertigo and then a coronary thrombosis with progressive angina.

Willie loved sport in all its forms. At varsity, he was awarded a blue as a catcher in baseball and played hooker for the 2nd rugby team, which was no mean feat as many of the 1st team played for Western
Province. He later took up golf and became a 10 handicap. He missed the accolade of being a single-figure player. He would stay up into the early hours of the morning to watch the last round of The Masters. He unfortunately developed macular degeneration and had to sit close to the TV screen to see the sports he loved. Despite all his disabilities, he remained equable to the last. Angina limited his walking to about 20 metres.

He was fortunate in that he was surrounded by a solid core of good friends, his faithful housekeeper Helena, a loving and devoted daughter Susan, and a sympathetic and capable GP of the same ilk as he was, to look after him. He fractured his right femur and 12 weeks later, the left one. He died in the presence of his daughter. It was a release from all the pain and disability he suffered. He was given a wonderful and moving eulogy by his minister, Jen Hands, in a church packed to overflowing.

We extend our deepest sympathy to his daughter Susan, his son-in-law David, his two grandchildren Andrew and Rosie, and Helena who was as competent as a trained nursing sister and of inestimable help in his terminal illness.

\section{R O Wise}

Durban

wisel@mweb.co.za 